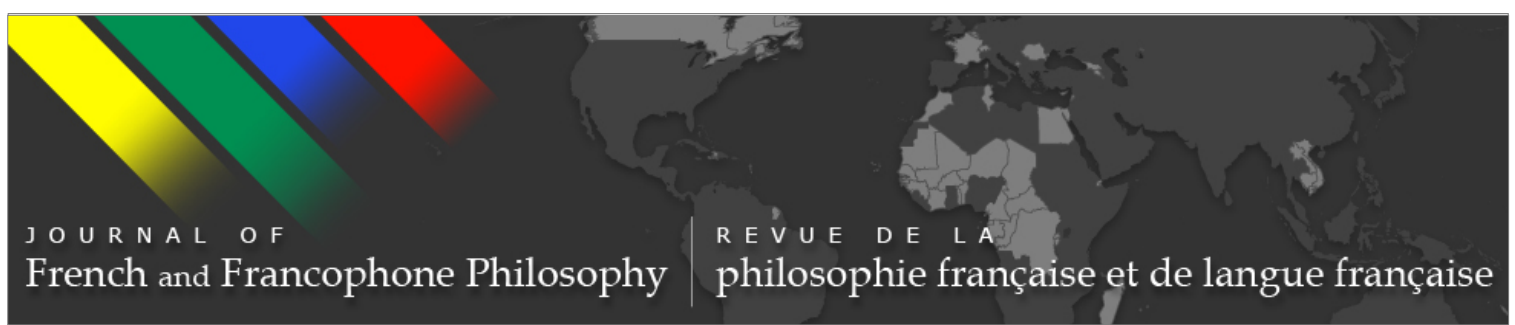

\title{
The Curiosity at Work in Deconstruction
}

\section{Perry Zurn}

Journal of French and Francophone Philosophy - Revue de la philosophie française et de langue française, Vol XXVI, No 1 (2018) pp 84-106

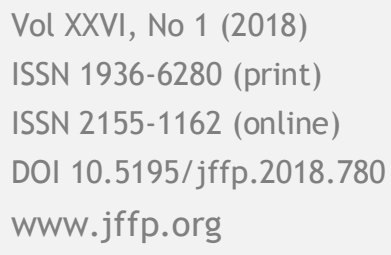

Thi (co) KEir-lingeinad under a Creative Commons Attribution-Noncommercial-No Derivative Works 3.0 United States License.

\section{UILIS D-Sork}

This journal is operated by the University Library System of the University of Pittsburgh as part of its D-Scribe Digital Publishing Program, and is co-sponsored by the University of Pittsburgh Press 


\title{
The Curiosity at Work in Deconstruction
}

\author{
Perry Zurn \\ American University
}

In the Honor of Thinking, Rodolphe Gasché argues that Jacques Derrida thinks "without wonder." ${ }^{1}$ By this he means that Derrida's thought has no proper philosophical beginning. Deconstruction is always already underway within the text and overtaken by its structural forces. But, if deconstruction does not start with wonder, then what? Where does Derrida begin? How does he begin in the face of his resistance to beginnings? Donna Haraway suggests that deconstruction begins with curiosity. Derrida, she writes, is "the most curious of men," because he spots and responds to what interrupts and entangles us. ${ }^{2}$ Hélène Cixous affirms that deconstruction is indeed driven by "a curiosity for sighs and hesitations," but she goes farther. She attests to sharing with Derrida a special curiosity: "a curiosity for the signifier, a greediness for tastetexts." ${ }^{3}$ Without composing a foundation or origin, does deconstruction nevertheless begin here, with curiosity? And what would that mean for philosophy? Is this even a legitimate source for philosophy or does Derrida's work stray from philosophy proper precisely because it is too curious, wallowing in a distracted "freeplay" and lost in labyrinthine wanderings, as his detractors suggest? ${ }^{4}$

Although Derrida substantively analyzes curiosity as early as 1991, in his unpublished Répondre du secret lectures, and returns to it in 1997, via The Animal That Therefore I Am, it is in The Beast and the Sovereign I, Session 11, that he provides his most robust accounting of curiosity, which inevitably involves bringing it to account. " "It's a fine word," Derrida writes, "a very fine verbal animal, curiositas." 6 The Latin curiositas is composed, as he points out, of two heads or two senses. On the one hand, and following the valence of curio, curiositas indicates an interrogating gaze set on an object. On the other hand, following cura, curiositas indicates the act of caring for someone or something. Each sense involves a particular treatment [traitement], in the double sense it has in French: curiositas may be expressed in the careless, detached handling of an object, or it may generate the regulated care of therapy. These two modes

Journal of French and Francophone Philosophy | Revue de la philosophie française et de langue française Vol XXVI, No 1 (2018) | www.jffp.org | DOI 10.5195/jffp.2018.780 
of curiosity, Derrida suggests, are fruitfully illustrated through two moments in French history: 1) the 1681 autopsic dissection of an elephant in the court of Louis XIV and, less than a century later, 2) the therapeutic confinement of animals and humans in zoological gardens and asylums. I will call these two modes of curiosity autopsic and therapeutic, or dissecting and confining, respectively.

While distinguishable, these two curiosities are, as Derrida demonstrates, modalities of a sovereign style of curiosity. Sovereignty is an illusion upon which, nevertheless, reason, knowledge, and power are built; in deciding "on what is [qu'est-ce que],"7 the sovereign claims sovereignty by circumscribingor asserting the limits—of words, beings, and states. Insofar as the autopsic and therapeutic modalities of curiosity negate the inherent instability of objects, divisions, walls, and procedures, they shore up the illusion of sovereignty, whether in the political or philosophical arena.

Autopsic curiosity is a drive to dissect an object in the service of knowledge, cleanly separating one thing from another. Therapeutic curiosity is a drive to confine an object in the service of care, definitively isolating one thing from another. These modalities of curiosity, therefore, function within regimes of knowledge and treatment that capitalize on illusions of mastery. Derrida thus provides a damning critique of curiosity, leaving open the question of whether there are other echoes in curiositas that might harbor a curiosity less bound by traditional and often violent illusions; a curiosity more responsive to difference and reconciled with finitude; a style of curiosity he himself might endorse or at least welcome as an attribution.

In what follows, I first explore the contentious attribution of curiosity to Derrida and deconstruction, before I turn to establish his critique of curiosity. I then argue there is a deconstructive style of curiosity that inhabits, resists, and disorganizes the sovereign style of curiosity in both its autopsic and therapeutic modalities. Because this account is only implicit within The Beast and the Sovereign I, I turn to Derrida's earlier work on curiosity, in The Animal That Therefore I Am and Répondre du secret, to illustrate how curiosity can function deconstructively within texts and taxonomies. I demonstrate that deconstructive curiosity textually resists the autopsic by not allowing a clean dissection of terms and resists the therapeutic by compromising the clean confinement of terms. In doing so, it ruptures taxonomical distinctions between the human, animal, and plant. I conclude that, if curiosity is not governed by some final teleology, nor does it end in certainty, but rather, in an exemplary comportment of exploration, it tracks, probes, and suspends itself, as if to emphasize the meandering and precarious quality of knowledge, it must be traceable across species lines, well beyond the bounds of the human, which turns out to be just another sovereign illusion. Indeed, this suggests that Derrida's practice of a deconstructive curiosity takes up a third, buried sense of curiositas, which precisely undergirds the other two: a clever,

Journal of French and Francophone Philosophy | Revue de la philosophie française et de langue française Vol XXVI, No 1 (2018) | http://www.jffp.org | DOI 10.5195/jffp.2018.780 
fanciful attention to the seemingly trivial, which has, nevertheless, been made secret or of little import.

Finally, I develop the implications of the deconstructive style of curiosity for the discipline of philosophy. Revisiting an exchange between Derrida and Sarah Kofman, I argue that deconstructive curiosity combats the illusions of pure revelation, whether through politics, science, scripture, or art, and instead draws attention to the conjuring trick, the systematic substitution of signs, that undergirds those illusions. In each case, deconstructive curiosity proliferates uneasiness and destabilizes sovereign impetus. While Derrida's critique of curiosity impinges on history and science, aesthetics and phenomenology, his ultimate target is, as I will show in closing, the sovereign practices of traditional philosophy. The Platonic paradigm of Western philosophy proceeds to essences by way of diaresis and epimeleia heautou, dissection and self-care, as anchored in the human mind. Against this tradition, Derrida weaves a deconstructive curiosity that bedevils ahistorical concepts, displaces the centrality of the human in philosophy, and calls attention to the sleights of reason by which philosophy is enshrined as pure, abstract, and glorified. The deconstruction of curiosity here becomes the deconstruction of philosophy. The curious work of deconstruction, then, is not to abolish philosophy in any final way, but to re-conceive it as the practice of an exuberant, though no less hesitant curiosity.

\section{"The Most Curious of Men"}

In Infinitely Demanding, Simon Critchley argues that philosophy does not begin in wonder at the things that exist but rather in a disappointment that things are not what they might be. ${ }^{8} \mathrm{He}$ is not the only one to suspect that reflective thinking is anything but wonderful. For Gasché, it is the honor of thinking to challenge the limits and the foundations of critique, theory, and philosophy. Gasché specifically addresses wonder. While philosophy may begin in wonder, thinking, real thinking-this is also for him deconstructive thinking - thinks without wonder. For Gasché, to think without wonder is to think without several basic assumptions that undergird the experience of wonder as traditionally conceived from Plato to Heidegger: that truth is universally accessible, by a unified subject, through fundamental philosophy. ${ }^{9}$ We have, in wonder, "a metaphysics of the subject," an "anthropology," and "features of humanism." ${ }^{10}$ It is quite worrisome for Gasché that wonder presumes a gulf between subject and object, knower and known, the one who wonders and the wonderful. We can presume, Gasché argues, despite Derrida's relative silence on the matter, ${ }^{11}$ that deconstruction necessarily does not begin in wonder and is not reducible to wonder because deconstruction functions on precisely the deterioration of these gulfs. This is but one of the reasons deconstruction signals the end of 'philosophy' as such.

In one sense, Haraway begins When Species Meet where Gasché finished. Without addressing deconstruction's turgid relationship to wonder, Haraway

Journal of French and Francophone Philosophy | Revue de la philosophie française et de langue française

Vol XXVI, No 1 (2018) | http://www.jffp.org | DOI 10.5195/jffp.2018.780 
states straightaway: "Derrida is the most curious of men, among the most committed and able of philosophers to spot what arrests curiosity, instead nurturing an entanglement and a generative interruption called response." 12 For Haraway, deconstruction begins not with what arrests us, or stops us short-like wonder, but rather in what increasingly entangles and disrupts us-something she calls 'curiosity.' Deconstruction in this sense has a genesis, but that genesis is an irreducibly enmeshed beginning where, as she states, "to be one is always to become with many." ${ }^{13}$ Before Haraway goes on to develop a robust cyborgism, focusing on the imbrication of the natural and artificial, she locates Derrida's perhaps most enmeshed curiosity in The Animal That Therefore I Am. In his analysis of his cat staring up at his naked body, Derrida deftly disrupts the binaries between human, animal, and machine around the question of responsivity (and responsibility). While indebted to his analysis in important ways, Haraway nevertheless faults Derrida for not being curious enough about the curious cat to ask, "Can animals play? Or work? And even, can I learn to play with this cat? Can I, the philosopher, respond to an invitation or recognize one when it is offered?"14

While I take Haraway's point that Derrida incuriously abandons the cat-and many still wish Derrida had written a treatise on cats-it would be incurious itself to assume all curiosity is absent in the remainder of The Animal That Therefore I Am. Indeed, the curiosity at work in deconstruction is always already activated at the textual level. Writing as a philosopher (against philosophy), Derrida here works within and at the limits of several material and theoretical texts, including previous Cerisy conferences, Derrida's own oeuvre, Genesis 1-3, and Alice in Wonderland. Deconstruction begins where it is, already inside a text, already in relationship to another, not over and against an object. To return to Gasché, deconstructive thinking is curiously compelled by the multi-valent resources of any given text. In turn, it sets out to compel every dominant discourse with the resistant resources within that discourse itself. If there is any wonder-or curiosity-at the outset of deconstruction, then, it is "nothing less than an awareness of being overtaken" by language and a corresponding impetus "to catch unawares and overtake" through the instability of discursive words themselves. ${ }^{15}$ Curiosity in deconstruction works with/in the text.

It is Cixous, Derrida's intimate interlocutor, who offers the most robust account of this curiosity so fundamental to Derrida and deconstruction. ${ }^{16}$ In Rootprints, she defines curiosity as "this urgency, this need to decipher what cannot be said, what is expressed otherwise than in verbal speech which nonetheless arouses the desire for words." 17 This curiosity for what is before language, which nevertheless exists in language, is something that both Cixous and Derrida share. For them, this is a "vital curiosity." It is a curiosity that breathes and that writes. It is a curiosity that breathes writing and that writes out of breath. ${ }^{18}$ In Insister, she offers concrete features of this vital, textual curiosity. It is an urgent need for the richness of language. It is the

Journal of French and Francophone Philosophy | Revue de la philosophie française et de langue française

Vol XXVI, No 1 (2018) | http://www.jffp.org | DOI 10.5195/jffp.2018.780 
desire to trace the excesses of words, which escape even as they appear. It is an electric attraction to colloquialisms, to etymologies, and to word plays. When Derrida and Cixous write to one another or for one another, they write between philosophy and literature, as if in a dream space. ${ }^{19}$ In this dream-like writing of these dream-texts, curiosity plays a central role:

[...] a curiosity for the signifier, a greediness for tastetexts, an inclination to jokes, Witz, witticisms, all those verbal penchants that lead us toward every kind of language activity or sport. With a curiosity for sighs and hesitations. And a curiosity for the abundantly stocked idiomatic storehouse of French of which in any and every context we exchange a few specimens that the worms had not gotten into. $^{20}$

The style of deconstructive curiosity mourned by Haraway is here seen and celebrated by Cixous. It is a curiosity for what is beyond language, for what exists in language, but particularly for what of the beyond exists in language such that language is overtaken, destabilized, and curiously compelled by itself.

Such a description of deconstructive curiosity sounds dangerously close, if not identical, to a common mischaracterization of Derrida by some of his critics. As Jonathan Kendall famously claims in his obituary for Derrida, deconstruction is mere language play, the indulgence of a few private curiosities repeated ad infinitum across innumerable, though hardly illuminated, texts. Deconstruction is "slippery," "murky," and "contortionist," proceeding by way of "puns, rhymes, and enigmatic pronouncements." 21 Such a misconstrual, Nicole Anderson notes, has been given academic pedigree by the likes of John Searle and Richard Rorty. ${ }^{22}$ In his review of Jonathan Culler's On Deconstruction, Searle describes the outcome of deconstruction in the following way: "What we think of as meaningful language is just a free play of signifiers or an endless process of grafting texts onto texts." ${ }^{23}$ For Searle, this makes deconstruction not only a failed literary theory, but a failed philosophy, as if Derrida's textual curiosity excludes him from the realm of the truly philosophical. For Rorty, Derrida does indeed "giv[e] free rein" to his "fantasies" and "trains of association," but this is in fact the requirement of liberal ironism. ${ }^{24}$ Where metaphysics has died, the only robust response is self-creation through contingent theorization.

Derrida's sympathizers, however, argue that his plays with words, genres, concepts, and arguments have more philosophical weight and rigor than Searle or Rorty would ever allow. Richard Klein, for instance, in his introduction to Derrida's interview entitled, "Positions," suggests that Derrida's performance of differance is no mere amusement. Rather, it is a means by which Derrida launches a substantial critique of philosophy. Klein

Journal of French and Francophone Philosophy | Revue de la philosophie française et de langue française

Vol XXVI, No 1 (2018) | http://www.jffp.org | DOI 10.5195/jffp.2018.780 
argues that Derrida does so by inviting, upsetting, and then refashioning our curiosity. First, differance "invites the intrusion of our eager curiosity." ${ }^{25}$ What will Derrida write? Will we finally access the truth? Then, it upsets our curiosity, so that "our curiosity -its misery or authenticity, its vulgarity or validity-[...] [is itself] put into question;" "we find our own impulses, ourselves, unaccountably on stage." 26 In doing so, Derrida confounds our illusions of access, whether metaphysics, idealism, teleology, spiritualism, logocentrism, essentialism, or history. Finally, differance highlights this curiosity - about the limits of curiosity and the illusion of the secret—which we might call deconstructive curiosity. Klein characterizes it as a Nietzschean, "vulgar curiosity" to see beneath the philosopher's discourse, call forth what has been repressed, and honor a basic materialism. ${ }^{27}$ Derrida thus curiously celebrates the inherent play of language in order to critique the foundations of philosophical curiosity.

In sum, scholars testify that Derrida is indeed driven by curiosity, may in fact harbor a deconstructive curiosity, and critically interrogates traditional philosophical curiosity. As it happens, Derrida himself bears witness to these claims. But we begin with his critique of curiosity in The Beast and the Sovereign.

\section{The Sovereign Practice of Curiosity}

The Beast and the Sovereign was Derrida's final seminar at the École des hautes études en sciences sociales. As such, it rather appropriately offers a rumination on finitude, solitude, and the limits of human existence-whether in plants or animals, despots or figure heads. Beasts and sovereigns come to a head in Session 11, where Derrida undertakes a critique of curiosity as it has been traditionally theorized and practiced: a curiosity applied by the sovereign subject to or upon a creaturely object. Although he opens with a promise to address not "this or that curiosity" but "just curiosity," as if it were some simple, unified thing, moreover, he closes with a reflection on this curiosity's inherent duplicity. Such curiosity aims to observe and it tries to cure. It is at once autopsic and therapeutic, dissecting and confining.

The culture of curiosity thus organizes the showing of curiosities for curious crowds, but the same culture of curiosity also had ambitions to treat, to care for, if not to cure. Or even to liberate by locking up differently. The cura of this curious curiosity always hesitated between two forms or two aims of what is always a treatment [traitement]. ${ }^{28}$

As I marked above, traitement has a duplicity that is analogous to that of sovereign curiosity, referring to careful treatment but also to coarse handling. The Latin cura, likewise, has two sides. Sometimes it is used to mark attentive inquiry. At other times, it means administrative oversight. Derrida argues

Journal of French and Francophone Philosophy | Revue de la philosophie française et de langue française

Vol XXVI, No 1 (2018) | http://www.jffp.org | DOI 10.5195/jffp.2018.780 
here that pre- and post-revolutionary France offer a perfect demonstration of curiosity's duplicity, ranging from animal autopsy under Louis XIV to zoological gardens and mental asylums of the classical period.

In 1662, Louis XIV established the Menagerie of Versailles, where, under the auspices of the Académie des Sciences, a variety of creatures were collected, studied, and dissected. ${ }^{29}$ Perhaps the most spectacular of these dissections occurred in 1681, when an elephant was carved up before the court and Louis XIV himself. ${ }^{30}$ This first, autopsic curiosity is "a seeing, a theatrical theorein, a gaze cast onto a visible ob-ject, a primarily optical experience that aims to touch with the eyes what falls under the hand, under the scalpel." ${ }^{31}$ Like the pure theorein of the eidos of Western philosophy, this modality of curiosity aims to reveal what is hidden through the exercise of a tactile sight that is at once disciplined and discursive. Skin is peeled from muscle, ligature, and bone. Joints are separated. Each cut unveils the nerves, arteries, and veins below. With this sort of sovereign curiosity, things are best seen when they are least alive.

The French Revolution deemed the Menagerie of Versailles a spectacular waste of human wealth and animal life. Such collections, however, were not entirely obliterated. They survived in the form of 19th century zoos and asylums. ${ }^{32}$ Here, a second modality of curiosity appeared: the therapeutic. This curiosity had "the ambition or the pretension to treat, to care for, to take great care (cura) of what it was enclosing and objectifying and cultivating." 33 There was, correspondingly, a marked improvement in living conditions for beasts, as well as "madmen." Such care aimed not to identify some hidden truth but rather to manage behavior. It confined rather than dissected. Humans and animals were restricted, constrained, and placed in cell-like structures. Some were strapped to beds or locked in pens. Floors were padded or covered in hay. With this sort of curiosity, things are best treated when they are least free.

For Derrida, pre- and post-revolution France have a culture of curiosity that shifts its practices from dissection to asylum or from the autopsic gaze to the therapeutic hand. Nevertheless, what remains consistent, he suggests, is this culture of curiosity's intimate relationship to sovereignty. ${ }^{34}$ Whether curiosity constrains or confines, it does so to death. Autopsic curiosity is a matter of the "objectifying to death of the object." 35 Therapeutic curiosity, on the other hand, "consists in enclosing, depriving of freedom of movement and, hence, of freedom itself, hence of power, or power to see, to know, to have beyond certain limits, and hence of sovereignty." 36 Sovereign subjects exercise autopsic and therapeutic curiosities in such a way that they deprive their creaturely objects of self-sovereignty. Whether the curious gaze alienates beasts and "madmen" from itself or gathers them together, it dominates and subjectivizes them, denying them their sovereignty, their humanity, and even their animality.

Journal of French and Francophone Philosophy | Revue de la philosophie française et de langue française Vol XXVI, No 1 (2018) | http://www.jffp.org | DOI 10.5195/jffp.2018.780 
Derrida briefly asserts that the elephant's dissection under Louis XIV must be read within the larger context of medical history, depictions of anatomy, and Cartesian thought. He specifically states that Rembrandt's famous painting, "The Anatomy Lesson of Dr. Nicolas Tulp" (1632), which depicts the dissection of an executed criminal, must be taken into account. What Derrida does not mention here, however, is that this painting formed the subject of his tribute to Sarah Kofman. Kofman wrote a brief, posthumously published essay entitled "Conjuring Death: Remarks on 'The Anatomy Lesson of Dr. Nicolas Tulp.'”37 Derrida's memorial essay for Kofman, simply titled (or not titled) “.....," ${ }^{38}$ takes Rembrandt's painting and Kofman's commentary as its central texts. All three works-Rembrandt, Kofman, and Derrida's—offer a specific analysis of dissection, which then extends to a broader reflection on curiosity itself. Kofman in fact wrote a second, complementary essay on curiosity, entitled, "The Imposture of Beauty: The Uncanniness of Oscar Wilde's Picture of Dorian Gray." ${ }^{39}$ In this instance, Kofman is concerned not with the cut of a scalpel but with a painting that captures-indeed, confines-Dorian. By analyzing both of Kofman's texts, through Derrida's memorial essay, I develop a deeper analysis of the sovereign style of curiosity, its nature and Derrida's critique thereof.

Rembrandt's commissioned piece depicts the annual public dissection, sponsored by Amsterdam's Guild of Surgeons and undertaken by Dr. Tulp, the guild's Praelector Anatomiae. ${ }^{40}$ The event took place on January 31st, 1632, in Amsterdam's Anatomy Theatre (1639-1690), housed above a meat market in the convent chapel of St. Margriet, patron saint of pregnant and laboring women. ${ }^{41}$ The subject of dissection was a recently hanged recidivist thief, by turns referred to as Adrian Adriaenz or Aris Kindt, who was given a Christian burial as recompense for his posthumous service to God and country. Besides the guild members, the remaining guests were all notable persons, capable of paying a handsome price for their seat, a collection from which no doubt some of Dr. Tulp's own remuneration was taken. The anatomy demonstration was, thus, at least as much an indication of wealth as it was a display of knowledge.

In "Conjuring Death," Kofman develops her own critique of curiosity. She begins by identifying the supposed lesson of the "Anatomy Lesson." Dr. Tulp is surrounded by seven doctors; together, they compose the perfect body or corporation [font corps] of knowledge production and dissemination. ${ }^{42}$ This medical body, however, is entirely disembodied: almost everything beneath the white ruff at the doctors' necks is shrouded in black. What is eminently visible is the cadaver. Lying nearly naked on a wooden table, with the vascular and skeletal structure of its left hand and forearm delicately splayed open, the hidden body appears doubly unveiled. This is Dr. Tulp's lesson: the secret of the human body revealed. Kofman suggests, however, that the lesson is not successful. Although the cadaver is twice bared for all to see, every eye, without exception, is trained either on the anatomy book at its feet or on the

Journal of French and Francophone Philosophy | Revue de la philosophie française et de langue française Vol XXVI, No 1 (2018) | http://www.jffp.org | DOI 10.5195/jffp.2018.780 
audience. No one is looking at the object of dissection. The object of dissection not only goes unnoticed, it also goes unnamed, lying there "in absolute anonymity." 43 The book, taking the place of both natural and spiritual revelation, is much like the cadaver, in that it goes unnamed and only the tip of its left page is displayed. In this multi-layered scene of visibility, then, Kofman traces what such visibility makes invisible.

The role of the book in "The Anatomy Lesson," at least from Kofman's perspective, really cannot be fully appreciated without reference to The Picture of Dorian Gray. Wilde's novel is a devastating tale. It begins with Dorian becoming bewitched by Lord Henry's hedonism. Such an intense desire to experience the limits of sensual pleasure leads Dorian to sever his young beautiful body from his aging, slowly corrupting soul. The latter is caughtor confined-in his friend Basil Halward's painting of him. As Dorian goes about his life, he obsessively returns to the painting, which lies upstairs, in a locked room, behind a thick curtain. He returns "more and more curious." 44 On Kofman's reading, Dorian's behavior can be explained as his futile attempt to conjure up, within his own face, an image of his mother's beauty and thereby conjure away the truth that she is not only dead, but she has been decomposing now for some time. The Picture of Dorian Gray is therefore the story of a curious melancholy, a failure to mourn that inspires an obsessive, curious return. ${ }^{45}$ The conjuration at work here functions not through dissection this time but through confinement, a confinement whereby Dorian saves, cares for, preserves, and protects his own visage. While that visage was extracted by a rift between body and soul, a cut, a "knife thrust," 46 it is now preserved, sealed off through enclosure-much like Dr. Tulp's book.

Throughout her ruminations on "The Anatomy Lesson" and The Picture of Dorian Gray, Kofman demonstrates not only that curiosity naturally saps life and freedom, but that curiosity structurally covers over what it investigates. Kofman theorizes this duplicity in two ways. First, curiosity dissimulates in the very act of disclosure. In their "intense curiosity" for the "secret," both the doctors and Dorian conceal the body they unveil. Second, curiosity represses in the very act of calling forth. "The fascination is displaced," Kofman states, "from the sight of the cadaver to that of the book," 47 or from the body to the mirror. Sovereign curiosity-whether autopsic or therapeutic, dissecting or confining curiosity-ultimately is such that it bears on a split, a cut, a severance and produces two costly confinements: one of pure illusion and one of de-contextualized matter. In either case, curiosity functions on devastating, deadening, and debilitating illusions. For Kofman, this is the double face of sovereign curiosity.

In his tribute to Kofman, Derrida is quick to grant her critique of curiosity. The doctors-and, by extension Rembrandt and their various audiences- "triumph over death," as he explains, by "trying to forget, repress, deny, or conjure away death." ${ }^{48}$ He then pauses over Kofman's term of choice here: conjuration. "To' conjure death,'” Derrida writes, "implies both

Journal of French and Francophone Philosophy | Revue de la philosophie française et de langue française

Vol XXVI, No 1 (2018) | http://www.jffp.org | DOI 10.5195/jffp.2018.780 
to conjure it up and conjure it away [...] and thus to pursue the other as the other dead." ${ }^{49}$ Such conjuration, in its very denial of death through curiosity, nevertheless 'pursues the other as the other dead' - whether dead on a slab (like Adriaenz or the elephant), dead in an anatomy book, dead in a painting (be it Rembrandt's or Basil Hayward's), or dead in a majestic floor-length mirror. It is reminiscent of the Eucharistic displacement and disavowal of the body into something else. Both autopsic and therapeutic curiosities, dissecting and confining curiosities, save their objects by conjuring them away and replacing them with an illusion. He writes:

'This is my body,' 'keep it in memory of me,' and so, 'replace it, in memory of me, with a book or discourse to be bound in hide or put into digital memory. Transfigure me into a corpus. So that there will no longer be any difference between the place of real presence or of the Eucharist and the great computerized library of knowledge. ${ }^{50}$

Derrida's alignment of conjuration with "the Eucharistic paradigm" elucidates the curiosity we see across Rembrandt and Kofman, Christ's body and the medical textbook. The practice of sovereign curiosity attempts to save, preserve, and know its objects by 'bloodless abstraction' ${ }^{\prime 51}$ so that what feels alive - whether knowledge, beauty, or truth—is always already dead. This is the unique work of sovereign curiosity that Kofman uncovers and Derrida emphatically confirms and critiques.

\section{A Deconstructive Style of Curiosity}

How might curiosity be practiced otherwise, against the sovereign illusion of mastery, of clean dissections or safe confinements? How might curiosity challenge, rather than capitalize on, the subject/ object distinction or the human/animal divide, whether at the level of texts or lived taxonomies? That is, what are or might be the elements of a deconstructive style of curiosity? And, in what sense, does such a style reprise certain resources hidden within curiositas that subtend the two classical senses of inquiry and care, autopsy and therapy? As I will argue, by developing the implicit descriptions of a deconstructive style of curiosity in The Beast and the Sovereign through The Animal That Therefore I Am and Répondre du secret, deconstructive curiosity is marked by hesitation and attention, playfulness and exploration not as distinct modalities but as fast proliferating modes of investigation. Because such modes belie the by turns brazen and whimsical meddlesomeness of a curiositas beyond its station, they immediately unsettle the too-easy alignment of curiosity with the human. Indeed, Derrida provides clues to a deconstructive style of curiosity precisely by reflecting on curious practices at the level of the animal, the vegetal, and the divine.

Derrida opens The Beast and the Sovereign I, Session 11, with a somewhat cryptic remark that curiosity is a "fine word," a "very fine verbal animal." In

Journal of French and Francophone Philosophy | Revue de la philosophie française et de langue française

Vol XXVI, No 1 (2018) | http://www.jffp.org | DOI 10.5195/jffp.2018.780 
contrast to his use of the neologism animot, ${ }^{52}$ by which he marks that animality is a linguistic construct, Derrida's characterization of curiosité as an animal, even a verbal animal, indicates that language itself is somehow non-human. What might this mean? This animal of a word, which Derrida uses throughout this session of The Beast and the Sovereign to mark sovereign power, is itself not sovereign. It moves from one meaning to another, from one practice to another, across shifts and slips of sense. Curiosité is overtaken by the inner resources of curiositas. And, in doing so, this verbal animal 'curiosity' can refer to a style of curiosity beyond the sovereign and beyond the human.

Across philosophical history, curiosity is often characterized as properly human, not animal. Thomas Hobbes, for example, in the Leviathan, argued that curiosity is essentially a rational faculty, an interested inquiry into causation, that separates humans from animals. ${ }^{53}$ Resisting this basic opposition, Derrida troubles the alignment of curiosity with humans-and in fact multiplies its alignments first of all with animals. Before demonstrating this through The Beast and the Sovereign and The Animal That Therefore I Am, it is helpful to briefly review the scholarship on Derrida's deconstruction of animality and humanity, especially with regard to curious questioning. In This is Not Sufficient, Len Lawlor remarks on how Western thought has typically denied animals the ability to question and to think, to answer and to name, but it has granted those abilities to humans. ${ }^{54}$ We have and they have not. ${ }^{55}$ Following Derrida, however, he insists that humans cannot ask a question either. True questions, questions worthy of the name, are unconditional questions, questions that are completely unreserved and open to what might come unannounced and unexpected. Irrespective of our personal limitations and investments, such questions are structurally impossible. We humans, then, like the animals, fail to question. ${ }^{56}$ This does not mean that there is no difference between a human and an animal but that both share a structural failure. The response to this failure ought to be, as Penelope Deutscher puts it, an "ethics of negotiation," one that aims to cultivate "a patient, attentive, negotiating relationship to the ways in which we fail the other." ${ }^{57}$

Such an ethics, or a "deconstructive responsibility,"58 should not be undertaken, as one might more easily believe, by mimicking animal vulnerability in our writing and thinking, ${ }^{59}$ but rather by attending to that very same vulnerability shared between texts and creatures, thoughts and beasts. After all, as Cixous says, "There is animal trace, animals write." ${ }^{60}$ What does this attentiveness look like? Lawlor thinks of it as writing like a cat: "when [Derrida] is writing aporias, he most resembles a cat pacing back and forth before a door, waiting to be let out or to be let in." ${ }^{61}$ David Krell, by contrast, imagines writing like a Bernese Mountain dog. Referring to the German verb sinnen, meaning to thoughtfully meditate, Krell remarks that such work "meditates by sniffing, pursuing a scent, following a trace left in the ice of high mountains." ${ }^{62}$ For Anne Berger and Marta Segarra, it means to

Journal of French and Francophone Philosophy | Revue de la philosophie française et de langue française

Vol XXVI, No 1 (2018) | http://www.jffp.org | DOI 10.5195/jffp.2018.780 
write scratching out or grafting new meanings "by nails or claws." 63 Whatever animal or animal activity it resembles, Lawlor insists that this writing uses the techniques of waiting, following, carrying, and 'notthinking. ${ }^{64}$ Together, such writing practices allow the development of what he calls 'weak thought' - the sort that negotiates with its own vulnerability. It is the sort of thinking that misses, redraws, and fires again. It slips and it slips up.

In The Beast and the Sovereign I, alongside his critique of sovereign curiosity, Derrida provides an implicit account of a deconstructive curiosity that is marked not by the illusion of absolute mastery but by a praxis of hesitation, humbly placing one foot in front of the other. Imagining a form of knowing inconsistent with the project of sovereign knowledge, Derrida speaks of "precisely the pas, the movement of a pas that consists in suspending with a 'who knows' and with so many 'perhaps's', [suspending] the order and the authority of a sure knowledge, precisely, a knowledge sure of itself." ${ }^{65} \mathrm{In}$ French, "pas" is a homonym, meaning both "not" and "step." This sort of knowing lifts its foot or its paw and suspends itself on a regular basis so as to negate any final achievement or command of the truth. If, following Erwin Straus, we understand walking as an act of "continuously arrested falling," and as "motion on credit," 66 such a pedetic pursuit of knowledge precisely cannot be fueled by autopsic or therapeutic curiosity, since it does not intrepidly divide or confine. Instead, it tries and tests; it slips and stretches. As such, it is impelled by a curiosity of a "perhaps," a "perhaps" that "abandons the shield of safety provided by power, presence, principle, and predictability," as John Caputo argues, and "follow[s] the tracks of a more radical possibilizing." ${ }^{67}$ It is a deconstructive curiosity that moves with exuberant hesitation.

In The Animal That Therefore I Am, Derrida refuses to begin from the sovereign position of knower and maker. Rather, Derrida suggests he will respond and he will follow: je suis. This style of inquiry involves not only lifting one's paw-or paws-but doing so repeatedly in order "to track, to sniff, to trail, and to follow" ${ }^{\prime 68}$ whatever has been denied voice, reason, or the honor of a question. It pitches its attention precisely against the grain of established hierarchies of value. Such an investigative mode, for Derrida, resembles the movement of an animal who, "finding its way on the basis of scent or a noise, goes back more than once over the same path to pick up the traces" or "pick up the scent." ${ }^{69}$ Writing and thinking in a way that honors the "perhaps" and the "who knows" is not just pedetic but olfactory and auditory; it is marked not simply by hesitation and the pause of a paw, but by an attention to the trace of an-other. For Michael Naas, this explains Derrida's flair; that is, his nose for the work and play of words. It is "a flair for language, true, but also for argument, and for the ways in which philosophical argument must always be tracked through the thickets of language; and claims [...] must always be followed, ferreted out, and picked apart." ${ }^{\prime 70}$ Derrida has a nose to

Journal of French and Francophone Philosophy | Revue de la philosophie française et de langue française

Vol XXVI, No 1 (2018) | http://www.jffp.org | DOI 10.5195/jffp.2018.780 
the ground, ferreting out the concepts, arguments, and systems that unsettle texts and taxonomies. ${ }^{71} \mathrm{He}$ attends not to the new, but to the 'already' that disrupts what is. ${ }^{72}$

A deconstructive style of curiosity is not only traceable in Derrida's cat, in the angle of a gait and the waft of a scent, but also far beyond the animal kingdom, in moments of divine playfulness and vegetal exploration. In their own way, each of these traces is a mode of inquiry inimical to sovereignty. In the Judeo-Christian tradition, God is precisely not curious because he is all knowing. ${ }^{73}$ Derrida, however, attributes curiosity-and therefore a certain ignorance-to this God. Returning to Genesis in The Animal That Therefore I Am, Derrida notes that God brings the animals before Adam "in order to see" what he would call them. ${ }^{74}$ "This 'in order to see," " Derrida writes, "marks at the same time the infinite right of inspection of an all-powerful God and the finitude of a God who doesn't know what is going to happen to him with language." 75 At this moment of radical divine vulnerability, God waits "with a mixture of curiosity and authority," ${ }^{76}$ wanting playfully "to abandon himself to his curiosity." 77 It's a dizzying thought. While Adam's curiosity is both autopsic and therapeutic, aiming to mark each animal by its own name and to confine animals to their own proper groups, God's curiosity waits to be surprised by another's retooling of sense and sociality, language and the fabric of materiality. Deconstructive curiosity flourishes precisely in this infinite play between words, between things, or between words and things.

Finally, in Répondre du secret, Derrida describes a "curiosity" of "vegetal being," by which he means the "exploratory comportment" of flowers or trees, plants or roots. ${ }^{78}$ "Curiosity," he writes, is typically defined as "the movement, the drive, or the desire to know;" ${ }^{79}$ if, however, it is broadened to mean "an exceptionally exploratory comportment of exploration," then "one is completely right to attribute some curiosity not only to humans and to animals, but also to living beings that do not belong to the animal realm: e.g., flowers and trees." 80 For Derrida, Avital Ronell comments, "there are acts of questioning which do not necessarily take recourse to discursivity. [...and] are not necessarily uniquely human. Plants may be questioning, too. [...] Vegetal beings show curiosity: a plant or a root probes." ${ }^{81}$ Indeed, plant exploration might extend to the dissemination of its seeds or the breaking open of its flowers. ${ }^{82}$ This vegetal mode of curiosity opposes specific illusions of sovereignty, such as absolute knowledge and independence, pure reason and teleological inquiry. Simultaneously, a vegetal mode of curiosity suggests an essayistic, vertiginous, and non-discursive praxis of inquiry. Such a praxis unsteadies the mythos that knowledge is inherently human, but also that knowledge is sure and steady, that it is based on staking claims more than stages of attention, and that it is more somber and serious than it is playful or breathless.

Deconstruction begins (and it is always just beginning) with a curiosity at the limits of language, text, and taxonomy. Derrida takes his argumentative

Journal of French and Francophone Philosophy | Revue de la philosophie française et de langue française

Vol XXVI, No 1 (2018) | http://www.jffp.org | DOI 10.5195/jffp.2018.780 
cues from the fault lines of French and dares to probe their vulnerability. It is in this sense that Derrida actually does ask and develop an answer to: what is a cat's curiosity? It is not a sovereign curiosity (like the autopsic or the therapeutic), but a deconstructive curiosity, one that tracks the scent of words and suspends its paw. It is a curiosity which, rather than opposing sovereign curiosity, slips through its clutches. Such a third curiosity challenges not only the illusion of a clean dissection or safe confinement, the definitiveness of a position or the stability of an opposition, but it also explores new, untested concepts and comportments. Fundamentally, such curiosity is a technique of deconstruction. It interrogates the limits of concepts, positional oppositions, and argumentative structures. It highlights the inherent instability of these critical elements and negotiates with that vulnerability. It is the philosophical implications of this criticality to which we now turn in closing.

\section{Philosophy After Wonder}

In this inquiry, we have seen why and how a deconstructive curiosity is deeply disruptive of sovereign curiosity. As a final step of this analysis, I want to explore the contours of that disruption at the level of philosophy. To do so, we must return to Kofman and to Derrida's reading of Kofman. There, we can trace a re-imagination of philosophy, contra philosophy, through the pathways of curiosity. ${ }^{83}$

Kofman certainly "points a finger" at the doctors, "protests" the conjuring movement, and "denounc[es] them to some extent." 84 While Derrida joins in the protest, he is interested in identifying the limits of Kofman's denunciation. While at one level, he argues, Kofman critiques curiosity, at another, deeper level, she practices and therefore affirms it. Kofman has written an essay. Like the doctors of Amsterdam, she too has displaced the body with the book. She, too, has swapped one corpus for another. In fact, upon her death, she left a large body of work. Derrida takes a moment to reflect on Kofman's corpus, pinpointing her texts on Nietzsche and Freud as exemplary. He remarks how Kofman displaces the body on the very same three registers of her critique: Dr. Tulp, Rembrandt, and the public. First, as if inspired by scientific curiosity, Kofman writes analytically. She analyzes books like Dr. Tulp dissects bodies, reading them "inside and out," as if her interpretations were "operations, experiences or experiments." ${ }^{85}$ Second, as if driven by artistic curiosity, Kofman writes revealingly. She interrogates philosophical questions like Rembrandt paints a figure, turning her lucidity, her "ray of living light," on a variety of issues, including death, melancholia, and sexuality. ${ }^{86}$ Third, in step with a long tradition of observations, interpretations, and commentaries, she has written speculatively or even scopophilically.

Like the auditing public, Kofman summons Nietzsche and Freud "to appear and [to] speak." ${ }^{87}$ In these ways, Kofman offers a bookish replacement

Journal of French and Francophone Philosophy | Revue de la philosophie française et de langue française

Vol XXVI, No 1 (2018) | http://www.jffp.org | DOI 10.5195/jffp.2018.780 
for the real cadaver, the real painting, even the real audience. What does it mean that "Conjuring Death" itself conjures death? What does it mean for Kofman to perform the very curiosity she critiques? What really is her position on curiosity ${ }^{88}$ Kofman performs her curiosity through the medium of philosophical reading and writing. Through a particular style of philosophy, Kofman constructs other bodies, another form of a corpus. In doing so, Derrida argues, she not only critiques the movement whereby the body is displaced, but also affirms the movement of philosophical curiosity itself and even the knowledges it produces.

She ends up affirming the triumph of life [...] not through the relinquishing of a knowledge of death, but, on the contrary, through an active interpretation that renounces neither knowledge nor the knowledge of knowledge, that is to say, the knowledge of the role that occultation or repression might still play in certain forms of knowledge. Whence the deployment of so many types of knowledge, the rigorous analysis of an intersemiotic and intertextual imbrication of speech, writing, and the silence of the body, of the sacred book and the book of science, book and painting, in more than one corpus. ${ }^{89}$

As Derrida observes, Kofman illuminates the dance whereby many, many forms of bodies are placing and displacing one another on the scene of life. To participate in this dance is as much an affirmation of life as it is a triumph over death. This affirmation, however, must be qualified. It is "without resurrection or redemption, without any glorious body." 90 Kofman does not participate in the Eucharistic movement whereby the body's displacement is erased through its glorification. Hers is a non-salvific philosophical method that precisely calls attention to the conjuring trick rather than trying to pass it off as real.

Derrida's reading of Kofman demonstrates his sense that there is a deconstructive form of curiosity that is not only eminently textual (bedeviling any separability of concept and argument) and taxonomical (belying any clear-cut distinction between the species), but is expressive of a philosophy against philosophy, understood in its best, most critical sense. Such curiosity looks behind the curtain, calling awkward and often highly disruptive attention to the mechanics whereby illusions are made and sustained. If, in any of its guises, sovereign curiosity feigns interest in the other, but ultimately refuses to face that other, this deconstructive style of curiosity opens onto the other. It is responsive. It refuses to function within the economy of repression. For this reason, it is deeply affirmative. Of course, the risk of uncovering the conjuration of death and affirming the instabilities of life is that both death and life newly demand our committed and constant negotiation. What is philosophy if it is not this work? Derrida might answer that traditional

Journal of French and Francophone Philosophy | Revue de la philosophie française et de langue française Vol XXVI, No 1 (2018) | http://www.jffp.org | DOI 10.5195/jffp.2018.780 
philosophy has in fact not grappled with life/death, but surreptitiously denied both.

For Plato, and for much of Western philosophy after him, philosophy begins in wonder: "this wondering [...] is where philosophy begins and nowhere else."191 Such wonder is injected with vertigo in the face of aporia and perhaps with pain at the hands of a sharp question. Thereafter, philosophy proceeds through dissection, or diaeresis, and ultimately develops into a form of self-care, or epimeleia heautou. Diaeresis is a particular form of philosophical dissection, where a definition is developed through extended bipartite analysis. Plato defines both the sophist and the statesmen in this manner, in his eponymously titled dialogues. This involves repeatedly cutting in two, grabbing hold of what falls to the right of the incision, and cutting again. ${ }^{92}$ This is how true essence is revealed. Epimeleia heautou is the therapeutic application of this scientific dissection to a philosophical life. As we see so well in the Apology, relentless inquiry forms the backbone of self-care. The one who heeds the Delphic Oracle and cultivates themself through an examined life- only this one is qualified to care for the city and lead it into its future. ${ }^{93}$ For Plato, there is an organic progression from the wonder-inducing questions, through the self-examination of dissection, to a politically viable life of care.

Insofar as autopsic curiosity is related to diaeresis and therapeutic curiosity to epimeleia heautou, the reading of Derrida's analysis undertaken so far would indicate that wonder-properly philosophical wonder, Platonic wonder-is intimately related to sovereignty. Such an indication supports Gasché's argument. If Derrida resists sovereign curiosity, it is only a matter of consistency to resist wonder as well. But philosophy, especially for Plato, does not only proceed by way of wonder, dissection, and self-care. It also proceeds, however inadvertently or tortuously, through semiotic language. Despite Plato's vituperous rejection of rhetoric in the Ion and Republic, we see that his dialogues follow not merely reason, but shifts and slips of sense, not only assertion but humor and overall a real stylistic craft. ${ }^{94}$ Derrida seems to begin in this margin, this elsewhere, this space in which words overtake and carry you along into recesses that rupture any stable sense of meaning or practice of inquiry. In fact, just as Derrida's critique of sovereignty supports his overall rejection of metaphysics, his critique of autopsic and therapeutic curiosity involves a re-imagination of philosophy. He demands that philosophy be done in another way and by other means.

One technique Derrida recommends for doing philosophy differently is, as I have argued, the practice of a deconstructive curiosity. I began by analyzing Derrida's commentators who suggest there is a distinctly deconstructive curiosity at work in Derrida's person, as much as in his texts. I turned to Derrida's treatment of autopsy and therapy, menageries and asylums, in The Beast and the Sovereign I to elucidate this curiosity as expressly

Journal of French and Francophone Philosophy | Revue de la philosophie française et de langue française Vol XXVI, No 1 (2018) | http://www.jffp.org | DOI 10.5195/jffp.2018.780 
in contrast to sovereign curiosity. Finally, I returned to Derrida's commentary on Kofman, through which he suggests that deconstructive curiosity may be expressed as a style of curiosity that affirms the vagaries and instabilities of life, while unmasking the conjuration of death. I concluded by placing this deconstructive style of curiosity within the context of the Platonic tradition. The former, fueled by what could be called, counter-intuitively, a 'rhetorical question,' literally asks for something other than to be answered. It asks to be destabilized, to be surprised, and to ask again.

Practicing philosophy in the style of a deconstructive curiosity is a multimodal enterprise. This is a kind of curiosity that uses language hesitantly, being particularly attentive to the work and play of words just as it explores what always somehow escapes words. It is a curiosity that refuses to keep the steady beat of knowledge and in fact mischievously renounces whatever access power and position are supposed to afford. It is a curiosity that sinks deep into the materiality of the earth in order to tentatively reach for resources and sow belonging. A curiosity that is not only far from human but deconstructs the taxonomies whereby the human is made superior to and separate from other living things. A deconstructively curious philosophy blithely fails to uphold illusions of mastery. It breaks metaphysical mirrors. And it refuses to construct any glorious body by investigating the other as a bloodless abstraction. It is a philosophy predicated on entanglement with whomever and wherever one finds oneself, and a responsiveness to that entanglement. It engages in an attentiveness to an-other or others discursively and/or materially denied voice, to textual elements that have been subordinated, and to histories that have been hidden or silenced. And its philosophical mindfulness is playful, open to surprise and humble before what ultimately cannot be controlled or claimed: the proliferation of difference in language and among the living. It is the sort of philosophy that puts down roots, less to secure and to establish than to build shared resources and community. Such a philosophy trails, and it wanders.

What are the implications for a Derridian account of curiosity? At the outset, Derrida's work aids us in understanding curiosity not as monolithically good or bad, but rather as a triumvirate of practices implicated in a series of hierarchies and responsibilities. By situating these various forms of curiosity in the history of science, Derrida pushes us to re-evaluate the progress of knowledge. Moreover, by unmooring curiosity-setting it adrift among plants, animals, humans, and beyond-Derrida implies that the ecological turn in philosophy will need to account for curiosity and work in tandem with revolutions in theology. Ultimately, however, a Derridian account of curiosity requires that we reconfigure philosophy. What would it mean if philosophy were driven by wonder no longer but by this deconstructive curiosity? Or perhaps it already begins in such curiosity, with the inquisitive modes of hesitation and attention, playfulness and exploration. If so, what would it mean to recognize that fact? To whom and for what would

Journal of French and Francophone Philosophy | Revue de la philosophie française et de langue française Vol XXVI, No 1 (2018) | http://www.jffp.org | DOI 10.5195/jffp.2018.780 
it matter? There is certainly a humility required here, at the level of texts and lived taxonomies, but also the honor of thinking with all the exuberance and poverty of organic life.

1 Rodolphe Gasché, “Thinking Without Wonder," The Honor of Thinking: Critique, Theory, and Philosophy (Stanford: Stanford University Press, 2007), 348-363. Thanks to Peggy Kamuf for this reference.

2 Donna Haraway, When Species Meet (Minneapolis : University of Minnesota Press, 2008), 20.

${ }^{3}$ Helene Cixous, Rootprints: Memory and Life Writing (New York: Routledge, 1997), 137.

${ }^{4}$ Michael Naas would call this mere "lexical play." See Naas, Taking on the Tradition: Jacques Derrida and the Legacies of Deconstruction (Stanford: Stanford University Press, 2003), xxvi.

5 Jacques Derrida, Répondre du secret (1991-1992), University of California, Irvine, Special Collections, MS-C01, Box: Folder: 21:4-9; Jacques Derrida, The Animal That Therefore I Am, trans. David Wills (New York: Fordham University Press, 2008); Jacques Derrida, The Beast and the Sovereign I, eds. Michel Lisse, Marie-Louise Mallet, and Ginette Michaud, trans. Geoffrey Bennington (Chicago: University of Chicago Press, 2009).

${ }^{6}$ Derrida, The Beast and the Sovereign I, 276.

7 Jacques Derrida, Death Penalty I (Chicago: University of Chicago Press, 2013), 222.

${ }^{8}$ Simon Critchley, Infinitely Demanding: Ethics of Commitment, Politics of Resistance (New York: Verso, 2008).

${ }^{9}$ Gasché, "Thinking, Without Wonder," 348, 353, and 356.

${ }^{10}$ Gasché, "Thinking, Without Wonder," 354.

${ }^{11}$ Gasché, “Thinking, Without Wonder," 353.

12 Haraway, When Species Meet, 20. Gayatri Spivak seconds this attribution. As she writes in "Class Individual: Gayatri Chakravorty Spivak on Jacques Derrida," Artforum International 43.7 (2005), “Derrida's insatiable curiosity about grasping it all kept him on the question of sexual difference. Curiously enough, Freud seemed not to have been his sourcebook for answers on this topic" (52). Then again, in "Notes Toward a Tribute to Jacques Derrida," Differences: A Journal of Feminist Cultural Studies 16.3 (2005), Spivak interprets Glas as an expression of Derrida's curiosity. There, as she says, he is "curious to see how much control he had over the name, not as mark but as sign” (103). Even Simon Critchley, in “Derrida: The Reader," Derrida's Legacies: Literature and Philosophy, eds. Simon Glendinning and Robert Eaglestone (New York:

Journal of French and Francophone Philosophy | Revue de la philosophie française et de langue française Vol XXVI, No 1 (2018) | http://www.jffp.org | DOI 10.5195/jffp.2018.780 
Routledge, 2008), will remark, "Derrida's work is possessed of a curious restlessness, one might even say an anxiety" (10).

${ }^{13}$ Critchley, "Derrida: The Reader," 4.

${ }^{14}$ Critchley, "Derrida: The Reader," 22.

${ }^{15}$ Gasché, “Thinking, Without Wonder," 362.

${ }^{16}$ See Cixous, Rootprints, 55 (definition of curiosity), 88, and 90, as well as Cixous, Insister of Jacques Derrida (Stanford: Stanford University Press, 2008), 14, 137, 141, and 177.

${ }^{17}$ Cixous, Insister of Jacques Derrida, 56.

${ }^{18}$ Compare the following passage from Cixous' Insister: “I open at random and at will any text at any page, certain as I am to find what for. What what for? Always at least two whats. Something is going to happen. I read you out of need, desire, vital curiosity [une curiosité vitale], together, for some glorious event of writing (for example the glorious appeasement). In order to breathe. When I read you, I breathe" (14).

${ }^{19}$ See Cixous, Three Steps on the Ladder of Writing (New York: Columbia University Press, 1993): "How can we finish a book, a dream" (98); "Difficult Joys," The Body and the Text (New York: Macmillan, 1991): "We should write as we dream" (22).

${ }^{20}$ Cixous, Insister, 137.

21 Jonathan Kendall, “Jacques Derrida, Abstruse Theorist, Dies at 74," New York Times, October 10, 2004.

22 Nicole Anderson, Derrida: Ethics Under Erasure (New York: Bloomsbury Press, 2012), 7.

23 John Searle, "The World Turned Upside Down," The New York Review of Books 30.16 (1983): 74-79.

24 Richard Rorty, Contingency, Irony, Solidarity (New York: Cambridge University Press, 1989), 125. While Rorty does claim that curiosity is a characteristic of the liberal ironist, he does not align curiosity with linguistic freeplay.

${ }^{25}$ Richard Klein, “Prolegomena to Derrida," Diacritics 2.4 (1972): 29. This serves as Klein's introduction to Derrida's interview entitled, "Positions," published in Diacritics 2.4 (1972): 35-43.

${ }^{26}$ Klein, “Prolegomena to Derrida," 29.

${ }^{27}$ Klein, “Prolegomena to Derrida," 30.

${ }^{28}$ Derrida, The Beast and the Sovereign I, 299.

29 Derrida refers throughout to Gustave Loisel's Histoire des ménageries de l'Antiquité à nos jours (Paris: Doin et fils, 1912) and Henri F. Ellenberger's "The Mental Hospital and the Zoological Garden," Canadian Psychiatric Association Journal 5.3 (1960): 136-149.

30 In "See Topsy 'Ride the Lightening': The Scopic Machinery of Death," The Southern Journal of Philosophy 50 (2012), 74-94, Kelly Oliver enriches our understanding of this

Journal of French and Francophone Philosophy | Revue de la philosophie française et de langue française Vol XXVI, No 1 (2018) | http://www.jffp.org | DOI 10.5195/jffp.2018.780 
scene by analyzing a similar display of human sovereignty: the execution of animals. For the long and sordid history of such a practice, see Edward Payson Evan's

The Criminal Prosecution and Capital Punishment of Animals (London: Heinemann, 1906).

31 Derrida, The Beast and the Sovereign I, 277.

32 Derrida, The Beast and the Sovereign I, 297.

33 Derrida, The Beast and the Sovereign I, 300.

${ }^{34}$ Grégoire Chamayou, in Les corps vils (Paris: La Découverte, 2008), argues that a sovereign autopsic curiosity remains alive well into the $19^{\text {th }}$ and $20^{\text {th }}$ centuries in the form of experimentation on criminals and the criminalized.

${ }^{35}$ Chamayou, Les corps vils, $274 \mathrm{n} 30$.

${ }^{36}$ Chamayou, Les corps vils, 300.

37 Sarah Kofman, "Conjuring Death: Remarks on 'The Anatomy Lesson of Dr. Nicolas Tulp,'” in Selected Writings, eds. Thomas Albrecht, Georgia Albert, and Elizabeth Rottenberg (Stanford: Stanford University Press, 2007), 237-244.

38 Jacques Derrida, “......," in The Work of Mourning (Chicago: University of Chicago Press, 2001), 165-188. Although Derrida is clearly responding to Kofman's 1995 essay, Kofman may well be indirectly responding to Derrida's comments on curiosity, the secret, and conjuration in The Gift of Death (1992; Chicago: University of Chicago Press, 1996) and Specters of Marx The State of Debt, the Work of Mourning, and the New International (1993; New York: Routledge, 1994).

${ }^{39}$ Sarah Kofman, "The Imposture of Beauty: The Uncanniness of Oscar Wilde's Picture of Dorian Gray," in Enigmas: Essays on Sarah Kofman, eds. Penelope Deutscher and Kelly Oliver (Ithaca: Cornell University Press, 1999), 25-48. For a comparative reading between "Conjuring Death" and "The Imposture of Beauty," see Pleshette DeArmitt's “Conjuring Bodies: Kofman's Lesson on Death," Parallax 17.1 (2011): 4-17.

${ }^{40}$ See William Heckscher, Rembrandt's Anatomy of Dr. Nicolaas Tulp (New York: New York University Press, 1958).

${ }^{41}$ Angela Vanhaelen, Comic Print and Theatre in Early Modern Amsterdam: Gender, Childhood and the City (Burlington: Ashgate Publishing, 2003), 191n129.

42 Kofman, "Conjuring Death," 237.

${ }^{43}$ Kofman, “Conjuring Death,” 238.

${ }^{44}$ Kofman, "The Imposture of Beauty," 34.

45 Kofman, "The Imposture of Beauty," 47.

46 Kofman, "The Imposture of Beauty," 30.

${ }^{47}$ Kofman, “Conjuring Death,”238.

48 Derrida, “......., 176.

${ }^{49}$ Derrida, “......., 171.

Journal of French and Francophone Philosophy | Revue de la philosophie française et de langue française Vol XXVI, No 1 (2018) | http://www.jffp.org | DOI 10.5195/jffp.2018.780 
${ }^{50}$ Derrida, “......, " 169.

51 Friedrich Nietzsche, Daybreak (Cambridge: Cambridge University Press, 2007), $\$ 105$.

${ }^{52}$ Animot is a neologism. It is a homonym of animaux (plural for animals) and conjoins the French animal and mot (meaning 'word').

53 Hobbes, Leviathan, vi.35.

${ }^{54}$ Leonard Lawlor, This is Not Sufficient: An Essay on Animality and Human Nature in Derrida (New York: Columbia University Press, 2007), 9.

55 Lawlor, This is Not Sufficient, 67.

56 Lawlor, This is Not Sufficient, 77.

${ }^{57}$ Penelope Deutscher, How to Read Derrida (New York: W. W. Norton, 2005), 64 and 82.

58 Deutscher, How to Read Derrida, 84.

${ }^{59}$ Kelly Oliver's argument for animal pedagogy-or "the ways in which animals [...] teach us how to be human"-resembles this approach. See Kelly Oliver, Animal Lessons: How They Teach Us to be Human (New York: Columbia University Press, 2009), 5.

${ }^{60}$ Hélène Cixous, “Jacques Derrida: Co-Responding Voix You," Derrida and the Time of the Political, eds. Pheng Cheah and Suzanne Guerlac (Durham: Duke University Press, 2009), 43. As quoted in Anne Emmanuelle Berger and Marta Segarra, “Introduction," Demenageries: Thinking (of) Animals After Derrida (New York: Rodopi, 2011), 4.

${ }^{61}$ Lawlor, This is Not Sufficient, 78.

${ }^{62}$ David Farrell Krell, Derrida and Our Animal Others (Bloomington: Indiana University Press, 2013), 164.

63 Berger and Segarra, "Introduction," Demenageries, 10. Berger and Segarra are drawing on Derrida's play with the coupe de greffe and coup de griffe in The Monolingualism of the Other. Another essay of interest in this collection is MarieDominique Garnier, “Animal Writes: Derrida's Que Donc and Other Tails” (23-40). Garnier argues that Derrida's heavy reliance on "k" sounds, throughout The Animal That Therefore I Am, relies on the common French association of this sound with what is foreign, uncouth, imperfectly naturalized, and animal; this would arguably include curiosité.

${ }^{64}$ Ibid., 79-96.

${ }^{65}$ Derrida, The Beast and the Sovereign I, 278.

${ }^{66}$ Erwin Straus, "Upright Posture" (1952), Phenomenological Psychology (New York: Basic Books, 1966), 148.

67 John D. Caputo, The Insistence of God: A Theology of Perhaps (Bloomington: Indiana University Press, 2013), 6.

Journal of French and Francophone Philosophy | Revue de la philosophie française et de langue française Vol XXVI, No 1 (2018) | http://www.jffp.org | DOI 10.5195/jffp.2018.780 
68 Jacques Derrida, The Animal That Therefore I Am, 33.

${ }^{69}$ Derrida, The Animal That Therefore I Am, 55.

${ }^{70}$ Naas, “Derrida's Flair," 219.

${ }^{71}$ Grégoire Chamayou would caution us here by marking that sovereign power has always and still expresses itself through hunts, especially the manhunt. See Les Chasses à l'homme (Paris: La Fabrique, 2010).

72 In the Western tradition, curiosity is often associated with the practice of following a scent. For Plutarch, the everyman or the busybody has a nose for news ("On Being a Busybody,") in Moralia VI (Cambridge : Loeb, 1939), 520e.

73 This understanding, of course, has created innumerable problems for philosophers of religion who attempt to safeguard human freedom in the face of divine omniscience. See, for example, Keith Yandell's Philosophy of Religion (New York: Routledge, 2002), Chapter 14.

${ }^{74}$ Genesis 2:19-20.

75 Derrida, The Animal That Therefore I Am, 17.

76 Derrida, The Animal That Therefore I Am, 16.

77 Derrida, The Animal That Therefore I Am, 17.

78 Ibid.

79 Derrida, Répondre du secret, December 11, 1991, manuscript p. 12 (my translation).

80 Ibid., December 11, 1991, manuscript p. 9 (my translation).

81 Ibid., 3-4 (my translation).

${ }^{82}$ See Elaine Miller, The Vegetative Soul: From Philosophy of Nature to Subjectivity (New York: SUNY Press, 2002) and Michael Marder, Plant Thinking: A Philosophy of Vegetal Life (New York: Columbia University Press, 2013).

83 For both Kofman and Derrida, this re-imagination of philosophy occurs in conjunction with the endorsement of psychoanalytic practice. Philosophy, in this sense, can be thought as a kind of therapy, a sort of therapy inconsistent with therapeutic confinement described above. See Mary Beth Mader, "Suffering Contradiction: Kofman on Nietzsche's Critique of Logic," Enigmas: Essays on Sarah Kofman, eds. Penelope Deutscher and Kelly Oliver (Ithaca: Cornell University Press, 1999): 87-96.

${ }^{84}$ Derrida, “.....," 180 and 169.

${ }^{85}$ Derrida, “....., 173.

86 Ibid. Rembrandt, of course, is known for his use of light and shadow.

87 Ibid.

${ }^{88}$ Kofman is certainly indebted to Freud for her sense of curiosity's involvement in philosophy, art, and sex. Kofman begins Camera Obscura (Ithaca: Cornell University

Journal of French and Francophone Philosophy | Revue de la philosophie française et de langue française Vol XXVI, No 1 (2018) | http://www.jffp.org | DOI 10.5195/jffp.2018.780 
Press, 1999) with a rumination on Nietzsche and Leonardo da Vinci on curiosity (0, 2934). She also addresses Freud's reading of curiosity and Leonardo in The Childhood of Art: An Interpretation of Freud's Aesthetics (New York: Columbia University Press, 1988), 166. Kofman speaks of an expressly sexual curiosity in a scene of her mother's nakedness in Rue Ordener, Rue Labat (Lincoln: University of Nebraska Press, 1996), 55. This could be compared to her discussion of sexual curiosity in The Enigma of Woman (New York: Cornell University Press, 1985), 9, 40, and 197. For her reading of Socrates as curious, see Socrates: Fictions of a Philosopher (Ithaca: Cornell University Press, 1998).

89 Ibid., 181.

90 Ibid.

91 Plato, Theatetus, $155 \mathrm{~d}$.

92 Plato, Sophist, 264e; cf. 253d-e. The subject of the Statesman is identified in the same manner; see 258b-266e.

93 Plato, Apology, 36c,; cf. Alcibiades I 124b and 129a.

94 Plato, Republic I and II (Cambridge: Loeb Classical Library, 2013), 398; cf. Ion, 535.

Journal of French and Francophone Philosophy | Revue de la philosophie française et de langue française Vol XXVI, No 1 (2018) | http://www.jffp.org | DOI 10.5195/jffp.2018.780 